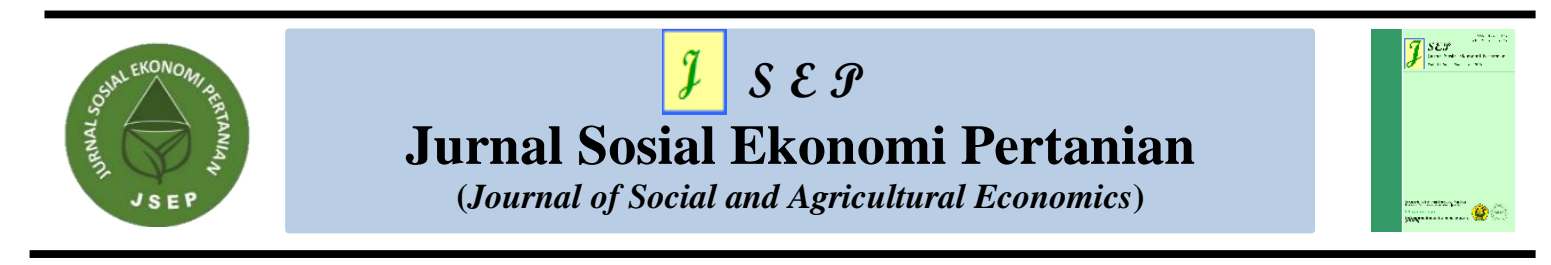

\title{
ANALISIS DETERMINAN TINGKAT PENGELUARAN KONSUMSI PANGAN DI JAWA TIMUR
}

\section{DETERMINANT ANALYSIS OF FOOD CONSUMPTION EXPENDITURE LEVELS IN EAST JAVA}

\author{
Ahmad Zainuddin ${ }^{1 *}$, Ratih Apri Utami ${ }^{1}$, Nurul Dwi Novikarumsari ${ }^{2}$ \\ ${ }^{1}$ Program Studi Agribisnis Fakultas Pertanian Universitas Jember \\ ${ }^{2}$ Program Studi Penyuluhan Pertanian Fakultas Pertanian Universitas Jember \\ *email: zainuddin91.faperta@unej.ac.id; 089682349116
}

Naskah diterima: 17/03/2020 Naskah direvisi: 28/03/2020 Naskah diterbitkan: 31/03/2020

\begin{abstract}
East Java is a province that has a high population, household consumption expenditure is an important thing to consider. The implication is that there will be an increase in production and investment in East Java. Therefore, household consumption expenditure is one of the determinants of community welfare. This study aims to analyze the structure of household consumption expenditure and the factors that influence food expenditure in East Java. The data used were secondary data from East Java in Figures 2019. This study was analyzed using multiple linear regression analysis. The analysis showed that there has been an increase in the welfare of the people of East Java. This is indicated by an increase in the amount of non-food expenditure is higher than food expenditure. Factors affecting household food expenditure in East Java are GRDP per capita, inflation rate, rice prices, and non-food expenditure. Based on these results it is suggested that the government needs to maintain the stability of prices of goods and services to avoid inflation because inflation will reduce public consumption and have implications for the economy of East Java.
\end{abstract}

Keywords: food expenditure, GDRP per capita, inflation

\begin{abstract}
ABSTRAK
Jawa Timur merupakan provinsi yang memiliki penduduk yang relatif padat, pengeluaran konsumsi rumah tangga menjadi penting untuk diperhatikan. Implikasinya, akan terjadi peningkatan produksi dan invetasi di Jawa Timur. Oleh karena itu, pengeluaran konsumsi rumah tangga merupakan salah satu penentu kesejahteraan masayarakat.Penelitian ini bertujuan untuk menganalisis struktur pengeluaran konsumsi rumah tangga dan faktor-faktor yang mempengaruhi pengeluaran pangan di Jawa Timur. Data yang digunakan adalah data sekunder dari Jawa Timur dalam Angka 2019. Penelitian ini menggunakan analisis regresi linier berganda. Hasil analisis menunjukkan bahwa terjadi peningkatan kesejahteraan masyarakat Jawa Timur dengan adanya peningkatan jumlah pengeluaran untuk non makanan lebih tinggi dibandingkan dengan pengeluaran untuk makanan. Faktor-faktor yang mempengaruhi pengeluaran pangan rumah tangga di Jawa Timur adalah PDRB perkapita, tingkat inflasi, harga beras dan pengeluaran non pangan. Berdasarkan hasil tersebut disarankan pemerintah perlu menjaga stabilitas harga barang dan jasa agar tidak terjadi inflasi, karena adanya inflasi akan menurunkan konsumsi masyarakat dan berimplikasi akan menurunkan perekonomian Jawa Timur.
\end{abstract}

Kata kunci: pengeluaran pangan, PDRB perkapita, inflasi

How to Cite: Zainuddin, A., Utami, R.A., \& Novikarumsari, N.D. (2020). Analisis Determinan Tingkat Pengeluaran Konsumsi Pangan Di Jawa Timur. JSEP: Jurnal Sosial Ekonomi Pertanian, 13(1): 91-98. 


\section{PENDAHULUAN}

Masalah konsumsi pangan dan pemenuhannya masih menjadi topik penting dalam pembangunan ekonomi di Indonesia. Status konsumsi pangan masayarakat masih menjadi salah satu patokan atau indikator dalam menentukan kesejahteraan masyarakat. Pembicaraan mengenai pangan merupakan pembahasan yang kompleks dan menyangkut dimensi yang luas. Dilihat dari sisi konsumsi dan permintaan perlu diketahui perubahan dan pola konsumsi antar waktu. Selain itu, faktor-faktor yang menyebabkan perubahan pola konsumsi juga variatif seperti tingkat pendapatan, preferensi, faktor demografis yang sangat dinamis (Anwar, 2010; Varlamova, J.; Larionova, 2015; Wibowo, 2000)

Konsumsi pangan merupakan salah satu determinan terhadap pertumbuhan ekonomi baik nasional maupun wilayah. Indikator pertumbuhan ekonomi nasional biasanya ditunjukkan oleh nilai Produk Domestik Bruto (PDB), sedangkan indikator pertumbuhan ekonomi suatu wilayah atau provinsi ditunjukkan oleh nilai Produk Domestik Regional Bruto (PDRB). Salah satu provinsi yang merupakan provinsi dengan jumlah penduduk yang padat dan memiliki tingkat PDRB yang relative tinggi adalah Jawa Timur. Jika dilihat pertumbuhan PDRB setiap tahunnya, Jawa Timur memiliki pertumbuhan yang relatif bagus (rata-rata di atas 5\%) (BPS, 2019). Peningkatan PDRB tersebut dapat disebabkan oleh beberapa faktor seperti konsumsi rumah tangga, pengeluaran investasi, pengeluaran pemerintah dan aktivitas perdagangan (ekspor impor) (Kusumawardhani, N.M.S.; Ayu, MS.; Made, 2012). Berdasarkan jenis pengeluarannya, kontribusi konsumsi rumah tangga terhadap PDRB dapat dilihat berdasarkan pengeluaran untuk konsumsi makanan dan non makanan.

Sebagai salah satu provinsi yang memiliki penduduk yang relatif padat, pengeluaran konsumsi rumah tangga menjadi penting untuk diperhatikan. Jumlah penduduk yang tinggi tentunya akan menyebabkan permintaan barang dan jasa juga meningkat (Rahardja, P.; Manurung, 2008). Implikasinya adalah akan terjadi peningkatan produksi dan invetasi dalam wilayah tersebut. Oleh karena itu, pengeluaran konsumsi rumah tangga merupakan salah satu penentu kesejahteraan masayarakat yang diukur dalam Indeks Pembangunan Manusia (IPM).

Kesejahteraan masyarakat juga dapat dilihat berdasarkan struktur pengeluaran konsumsinya yaitu pengeluaran untuk makanan atau makanan. Terdapat kecenderungan bahwa rumah tangga yang memiliki pendapatan yang relatif lebih tinggi memiliki share pengeluaran konsumsi non makanan lebih banyak dibandingkan dengan rumah tangga yang memiliki pendapatan yang rendah. Sebaliknya, rumah tangga dengan tingkat pendapatan yang rendah memilih lebih banyak mengalokasikan pendapatannya untuk mengkonsumsi makanan (Ekayana, A.; Lestari, E.; Qonita, 2013; Ilham, N.; Sinaga, 2007; Purwatiningsi, Y.; Hartono, S.; Masyhuri; Mulyo, 2010; Rachman, 2001). Namun penelitian ini hanya memfokuskan pada pengeluaran pangan penduduk di Jawa Timur.

Selain dilihat berdasarkan pengeluaran pangan dan non pangan, pengeluaran konsumsi juga dibedakan berdasarkan pengeluaran untuk masayarakat perkotaan dan pedesaan. Seperti dijelaskan sebelumnya bahwa tingkat pendapatan akan mempengaruhi jumlah pengeluaran. Berdasarkan hal tersebut, menjadi penting untuk meneliti mengenai struktur pengeluaran konsumsi rumah tangga di Jawa Timur.

Terdapat beberapa faktor-faktor yang mempengaruhi pengeluaran konsumsi rumah tangga. Salah satunya adalah variabel makroekonomi seperti faktor ekonomi, faktor non ekonomi dan faktor demografi. Faktor ekonomi seperti pendapatan, tingkat bunga, PDB/PDRB, dan lainnya. Faktor non ekonomi seperti kondisi sosial budaya masyarakat, kebiasaan, selera dan lainnya. Sedangkan faktor demografi yang dapat mempengaruhi pengeluaran konsumsi adalag jumlah penduduk, IPM, tingkat Pendidikan dan lain sebagainya. Dalam penelitian ini faktor-faktor yang akan diteliti adalah PDB/PDRB perkapita, inflasi, harga pangan, dan IPM.

Penelitian mengenai pengaruh variabel makro ekonomi terhadap pengeluaran konsumsi rumah tangga sudah pernah dilakukan. Penelitian (Wiranthi, 2014) menyebutkan bahwa faktor pendapatan nasional, tingkat suku bunga dan harga bahan bakar secara signifikan mempengaruhi pengeluaran konsumsi rumah tangga nasional. Penelitian (Burhanuddin; Lisna, V.; Rifai, 2013; Chioma, 2009; Illahi, N.; Adry, M.R.; Triani, 2018; Murohman, 2011; 
Persaulian, B.; Hasdi, A.; Ali, 2013; Siregar, 2009; Tapsin, 2014) menyimpulkan bahwa secara umum pengeluaran konsumsi rumah tangga di Indonesia dipengaruhi oleh PDB, suku bunga, inflasi, harga BBM, harga beras, IPM dan konsumsi periode sebelumnya. Selain itu, penelitian mengenai pola pengeluaran konsumsi pangan di Indonesia di daerah perkotaan dan pedesaan sudah pernah dilakukan oleh (Kuntjoro, 1984; Widjajanti, E.; Li, 1996) yang hasil penelitiannya menyimpulkan bahwa terdapat perbedaan antara pengeluaran pangan di pedesaan dan perkotaan. Penduduk pedesaan memiliki kecenderungan elastisitas pendapatan yang lebih besar dibandingkan di perkotaan. Penelitian sebelumnya lebih terfokus pada faktor-faktor yang mempengaruhi pengeluaran pangan serta perbedaan pola pengeluaran pangan di pedesaan dan perkotaan di Indonesia. Adapun kebaharuan penelitian ini adalah penelitian ini hanya berfokus pada struktur pengeluaran rumah tangga dan pengeluaran konsumsi pangan rumah tangga serta wilayah penelitian ini hanya di Jawa Timur.

\section{METODE PENELITIAN}

Data yang dikumpulkan dalam penelitian ini terdiri atas data sekunder. Data sekunder di tingkat Provinsi Jawa Timur diperoleh dari Badan Pusat Statistik (BPS) Jawa Timur yaitu pada tahun 2019. Data yang digunakan dalam penelitian ini antara lain data pengeluaran pangan masayarakat baik di pedesaan dan perkotaan (Rp), data pengeluaran non pangan masayarakat baik di pedesaan dan perkotaan (Rp), Data Inflasi di Jawa Timur (\%), PDRB di setiap Kabupaten di Jawa Timur (juta Rp); harga beras di setiap kabupaten di Jawa Timur (Rp), serta Indeks Pembangunan Manusia (IPM) di Jawa Timur.

Tabel 1. Jenis dan Sumber data penelitian

\begin{tabular}{|c|c|c|}
\hline No & Jenis Data & Sumber Data \\
\hline 1. & $\begin{array}{l}\text { Data Pengeluaran pangan per kapita per } \\
\text { bulan di pedesaan dan perkotaan Jawa } \\
\text { Timur }\end{array}$ & BPS Jawa Timur \\
\hline 2. & $\begin{array}{l}\text { Data Pengeluaran nonpangan per kapita per } \\
\text { bulan di pedesaan dan perkotaan Jawa } \\
\text { Timur }\end{array}$ & BPS Jawa Timur \\
\hline 3. & Data PDRB Jawa Timur & BPS Jawa Timur \\
\hline 4. & Data Inflasi & BPS Jawa Timur \\
\hline 5. & Data Harga beras & SISKAPERBAPO Jawa Timur \\
\hline 6. & Indeks Pembangunan Manusia (IPM) & BPS Jawa Timur \\
\hline
\end{tabular}

Model yang digunakan dalam analisis determinan tingkat pengeluaran konsumsi pangan pedesaan dan perkotaan di Jawa Timur adalah Model regresi linier. Adapun formulasinya sebagai berikut:

Dimana:

$$
\mathrm{Y}=\beta_{0}+\beta_{1} \mathrm{X}_{1}+\beta_{2} \mathrm{X}_{2}+\beta_{3} \mathrm{X}_{3}+\beta_{4} \mathrm{X}_{4}+\beta_{5} \mathrm{X}_{5}+\mathrm{e}
$$

$\mathrm{Y} \quad=$ pengeluaran konsumsi pangan perkapita pedesaan atau perkotaan di Jawa Timur (Rp)

$\mathrm{X}_{1} \quad$ = PDBR harga berlaku Jawa Timur (ribu Rp)

$\mathrm{X}_{2} \quad=$ tingkat inflasi di Jawa Timur (\%)

$\mathrm{X}_{3} \quad=$ harga beras $(\mathrm{Rp})$

$\mathrm{X}_{4} \quad=$ Indeks Pembangunan Manusia (IPM)

$\mathrm{X}_{5} \quad=$ Pengeluaran Nonpangan perkapita pedesaan atau perkotaan di Jawa Timur (Rp)

e $\quad$ error term

Pengujian hipotesis dalam penelitian ini adalah sebagai berikut:

1. Uji t (uji parsial)

Uji t menunjukkan seberapa besar pengaruh variabel bebas secara individual terhadap variabel terikat. Adapun Uji-t menggunakan langkah-langkah sebagai berikut: 
$\mathrm{H}_{0}: \beta_{1}=0$, artinya secara parsial tidak terdapat pengaruh yang positif dan signifikan dari variabel bebas terhadap variabel terikat.

$\mathrm{H}_{1}: \beta_{1} \neq 0$, artinya secara parsial terdapat pengaruh yang positif dan signifikan dari variabel bebas terhadap variabel terikat.

Kriteria pengambilan keputusan :

$\mathrm{H}_{0}$ diterima atau $\mathrm{H}_{1}$ ditolak, jika $\mathrm{t}$ sig. $>\alpha=5 \%$

$\mathrm{H}_{0}$ ditolak atau $\mathrm{H}_{1}$ diterima, jika t sig. $<\alpha=5 \%$

\section{Koefisien Determinasi}

Koefisien determinasi $\left(\mathrm{R}^{2}\right)$ digunakan untuk menjelaskan proporsi variabel dependen (bebas) yang mampu dijelaskan oleh variasi variabel independennya (terikat). Nilai koefisien determinasi adalah $0<\mathrm{R}^{2}<1$. Nilai $\mathrm{R}^{2}$ yang kecil berarti kemampuan variabel independen hampir memberikan semua informasi yang dibutuhkan untuk memprediksi variabel dependen (Ghozali, 2013; Hariyati, Y.; Rahman, R.Y.; Zainuddin, 2018).

\section{HASIL DAN PEMBAHASAN}

\section{Perkembangan Konsumsi Rumah Tangga di Jawa Timur}

Pengeluaran konsumsi rumah tangga pedesaan dan perkotaan terdiri atas dua pengeluaran yaitu pengeluaran konsumsi pangan dan pengeluaran konsumsi non pangan. Jika dilihat dari histori perkembangan pengeluaran konsumsi rumah tangga di Jawa Timut (Tabel 2), pengeluaran konsumsi cenderung mengalami peningkatan setiap tahunnya. Hal ini dapat terjadi karena adanya peningkatan pendapatan rumah tangga baik yang berasal dari penggunaan faktor produksi yang dimiliki seperti asset, tenaga kerja maupun modal, dimana penggunaan faktor produksi tersebut akan dikembalikan kepada rumah tangga dalam bentuk pendapatan sewa dan gaji (Dornbusch, R.; Fischer, B.; Startz, 2008; Rahardja, P.; Manurung, 2008)

Tabel 2. Perkembangan pengeluaran Konsumsi Rumah tangga tahun 2017-2019

\begin{tabular}{lcrr}
\multicolumn{1}{c}{ Variabel } & $\mathbf{2 0 1 7}$ & $\mathbf{2 0 1 8}$ & \multicolumn{1}{c}{$\mathbf{2 0 1 9}$} \\
\hline Pengeluaran Pangan (Rp) & 476.861 & 502.761 & 502.892 \\
Pengeluaran Nonpangan (Rp) & 461.940 & 503.317 & 533.285 \\
Total pengeluaran (Rp) & 938.801 & 1.006 .078 & 1.036 .177 \\
\hline
\end{tabular}

Sumber : (BPS, 2019)

Jika dilihat dari struktur pengeluaran pengeluaran konsumsi rumah tangga di Jawa Timur dapat diketahui bahwa pengeluaran Makanan pada tahun 2017 memiliki proporsi yang lebih besar dibandingkan dengan pengeluaran non makanan. Hal ini menunjukkan bahwa pada tahun 2017 tingkat kesejahteraan masyarakat di Jawa Timur masih tergolong rendah (mengacu pada hasil studi empirical Engle). Hal ini sesuai dengan penelitian (Kuntjoro, 1984; Widjajanti, E.; $\mathrm{Li}$, 1996) yang menyatakan bahwa penduduk dengan pendapatan rendah memiliki kecenderungan untuk mengkonsumsi makanan lebih banyak dibandingkan dengan penduduk yang memiliki pendapatan yang tinggi. Namun, pada tahun 2018 dan 2019 terjadi kontradiktif dimana pengeluaran non makanan lebih tinggi dibandingkan dengan pengeluaran pangan. Data tersebut menunjukkan bahwa terjadinya peningkatan kesejahteraan masyarakat Jawa Timur dimana masyarakat Jawa Timur mendorong peningkatan jumlah pengeluaran untuk non makanan lebih tinggi dibandingklan dengan pengeluaran non makanan.

\section{Faktor-faktor yang Mempengaruhi Pengeluaran Pangan di Jawa Timur}

Faktor-faktor yang diduga mempengaruhi konsumsi pangan di Jawa Timur adalah PDRB perkapita Jawa Timur, Tingkat Inflasi, harga beras, Indeks pembangunan Manusia, dan pengeluaran non pangan. Hasil analisis faktor-faktor determinan terhadap pengeluaran pangan di JawaTimur dapat dilihat pada Tabel 3. Hasil pengujian analisis regresi linier berganda 
terhadap faktor-faktor yang mempengaruhi pengeluaran konsumsi pangan di Jawa Timur tidak menunjukkan adanya penyimpangan data. Berdasarkan hasil analisis heteroskedastisitas, autokorelasi, normalitas dan multikolinearitas tidak menunjukkan bahwa model yang digunakan mengandung penyimpangan-penyimpangan tersebut, sehingga model yang digunakan dalam penelitian ini memiliki kemampuan memprediksi yang baik dan model dapat dikatakan fit. Koefisien determinasi yang dihasilkan dalam penelitian ini sebesar 0,753. Hal ini menunjukkan bahwa variabel independen seperti PDRB, inflasi, harga beras, IPM dan pengeluaran non pangan dapat mempengaruhi variabel dependen pengeluaran konsumsi pangan sebesar 75,3 persen, selebihnya dijelaskan oleh variabel lain di luar model.

Tabel 3. Hasil Estimasi Koefisien Regresi terhadap Pengeluaran Konsumsi Pangan di Jawa Timur

\begin{tabular}{|c|c|c|c|c|c|}
\hline Varibel & Koefisien & Standar Error & Nilai Uji-t & Sig. Uji-t & VIF \\
\hline Konstanta & 7679,003 & 237034,083 & 0,032 & 0,974 & \\
\hline PDRB perkapita & $0,375 * * *$ & 0,108 & 3,699 & 0,009 & 1,456 \\
\hline Inflasi & $-140724,88 * *$ & $-67770,59$ & $-2,076$ & 0,046 & 1,642 \\
\hline Harga Beras & $7,782 *$ & 18,731 & 2,005 & 0,081 & 1,276 \\
\hline IPM & 2540,37 & 2665,821 & 0,953 & 0,348 & 3,806 \\
\hline Pengeluaran & $-0,234 * * *$ & $-0,058$ & $-4,039$ & 0,000 & 3,466 \\
\hline \multicolumn{6}{|l|}{ Nonpangan } \\
\hline & Nilai Uji F & & 23,521 & Prob & 0,000 \\
\hline & R-square & & 0,786 & Adj R-Square & 0,753 \\
\hline
\end{tabular}

Keterangan: * signifikan pada $\alpha=10 \%$, ** signifikan pada $\alpha=5 \%$, dan *** signifikan pada $\alpha=1 \%$,

Sumber: (BPS, 2019), diolah

Tabel 3. di atas menunjukkan hasil bahwa faktor-faktor yang berpengaruh signifikan terhadap pengeluaran konsumsi pangan di Jawa Timur adalah PDRB perkapita, tingkat inflasi, harga beras dan pengeluaran non pangan. PDRB per kapita berpengaruh signifkan dan memiliki hubungan yang positif terhadap pengeluaran konsumsi pangan. Adapun nilai koefisien PDRB per kapita adalah sebesar 0,375. Nilai tersebut menunjukkan Marginal Propensity to Consume (MPC) terhadap pangan adalah sebesar 0,375. Artinya setiap peningkatan 1 juta rupiah pendapatan rumah tangga akan meningkatkan konsumsi pangan rumah tangga di Jawa Timur sebesar 0,375 juta rupiah, ceteris paribus. Hasil tersebut sesuai dengan penelitian (Burhanuddin; Lisna, V.; Rifai, 2013; Illahi, N.; Adry, M.R.; Triani, 2018; Wiranthi, 2014) yang menunjukkan bahwa pendapatan berpangaruh positif terhadap pengeluaran konsumsi rumah tangga. Hal ini juga sesuai dengan teori yang menyatakan bahwa konsumsi lebih banyak dipengaruhi oleh tingkat pendapatan dan nilai MPC akan berada diantara nilai 0 sampai dengan 1 (asumsi Keynes).

Tingkat inflasi memiliki pengaruh sebesar -140724,88. Nilai negatif tersebut menunjukkan bahwa jika terjadi inflasi dimana harga-harga mengalami peningkatan, maka rumah tangga akan merespon dengan mengurangi tingkat pengeluaran konsumsinya. Nilai 140724,88 dapat diartikan bahwa setiap peningkatan inflasi sebanyak 1\%, maka rumah tangga akan merespon dengan mengurangi pengeluaran rumah tangga terhadap pangan sebesar Rp. 140724,88. Hal ini merupakan tindakan rasional konsumen dimana jika terdapat peningkatan harga, maka konsumen akan mengurangi tingkat pembeliannya.

Harga beras juga memiliki pengaruh yang signifikan terhadap pengeluaran konsumsi pangan. Pengaruh harga beras sebesar 7,782. Harga beras memiliki pengaruh yang positif dimana jika harga beras terjadi kenaikan sebesar $\mathrm{Rp}$. 1 cenderung akan meningkatkan pengeluaran pangan sebesar Rp. 7,782. Hal ini sangat sesuai dengan teori dimana beras merupakan kebutuhan pokok, jika harga beras meningkat, maka konsumen cenderung akan tetap mengkonsumsinya sehingga adanya peningkatan harga akan berpengaruh terhadap meningkatnya jumlah pengeluaran pangan tersebut. Hal ini sesuai dengan penelitian 
(Burhanuddin; Lisna, V.; Rifai, 2013) yang menunjukkan bahwa harga beras akan meningkatkan pengeluaran rumah tangga.

Pengeluaran non pangan rumah tangga juga memiliki pengaruh negatif sebesar -0,234 Nilai tersebut menunjukkan bahwa setiap peningkatan pengeluaran non pangan sebesar Rp. 1, maka rumah tangga akan merespon dengan mengurangi konsumsi pangannya sebesar 0,234, ceteris paribus. Hal ini sesuai dengan penelitian (Widjajanti, E.; Li, 1996) yang menunjukkan bahwa respon rumah tangga terhadap pengeluaran pangan dan non pangan akan berkebalikan dimana jika konsumsi pangan meningkat, maka konsumen akan menurunkan konsumsi non pangannya, begitu pula sebaliknya. Hasil analisis ini menjadi indikasi yang positif dimana masyarakat Jawa Timur mulai mengalihkan alokasi pengeluaran untuk kebutuhan pangan cenderung mengalami penurunan, dan konsumsi non pangan mengalami peningkatan. Hal ini menunjukkan adanya kecenderungan peningkatan kesejahteraan masyarakat di Jawa Timur. Hasil ini diharapkan dapat dijadikan sebagai masukan bagi pemerintah khususnya pemerintah Jawa Timur untuk mendukung kebijakan pemerintah guna meningkatkan pertumbuhan ekonomi regional di Jawa Timur.

\section{KESIMPULAN}

Terjadi peningkatan kesejahteraan masyarakat Jawa Timur dimana masyarakat Jawa Timur mendorong peningkatan jumlah pengeluaran untuk non makanan lebih tinggi dibandingkan dengan pengeluaran makanan. Faktor-faktor yang mempengaruhi pengeluaran pangan rumah tangga di Jawa Timur adalah PDRB perkapita, tingkat inflasi, harga beras dan pengeluaran non pangan. PDRB per kapita berpengaruh signifikan dan memiliki hubungan yang positif terhadap pengeluaran konsumsi pangan. Nilai Marginal Propensity to Consume (MPC) terhadap pangan adalah sebesar 0,375. Artinya setiap peningkatan 1 juta rupiah pendapatan rumah tangga akan meningkatkan konsumsi pangan rumah tangga di Jawa Timur sebesar 0,375 juta rupiah. Tingkat Inflasi akan menurunkan konsumsi pangan rumah tangga di Jawa Timur. Harga beras berpengaruh positif terhadap pengeluaran pangan di Jawa Timur yaitu adanya peningkatan harga beras akan berpengaruh terhadap meningkatnya jumlah pengeluaran pangan di Jawa Timur. Selain itu, Terjadi indikasi yang positif dimana masyarakat Jawa Timur mulai mengalihkan alokasi pengeluaran untuk kebutuhan pangan cenderung mengalami penurunan, dan konsumsi non pangan mengalami peningkatan.

Pemerintah daerah khususnya Jawa Timur perlu menciptakan program-program untuk meningkatkan konsumsi masyarakat khususnya untuk konsumsi non pangan dimana data menunjukkan masyarakat mulai mengalokasikan pengeluaran mereka lebih banyak pada pengeluaran non pangan. Hal ini tentunya akan meningkatkan tingkat kesejahteraan masyarakat Jawa Timur dan meningkatkan perekonomian di Jawa Timur.Selain itu pemerintah perlu menjaga stabilitas harga barang dan jasa agar tidak terjadi inflasi, karena adanya inflasi akan menurunkan konsumsi masyarakat dan berimplikasi akan menurunkan perekonomian Jawa Timur.

\section{DAFTAR PUSTAKA}

Anwar, K. (2010). Analisis Determinan Pengeluaran Konsumsi Rumah tangga Miskin di Kabupaten Aceh Utara. Jurnal Aplikasi Manajemen, 8(4), 1168-1177.

BPS. (2019). Jawa Timur Dalam Angka 2019. BPS Jawa Timur.

Burhanuddin; Lisna, V.; Rifai, N. (2013). Analisis Ekonomi Makro yang Memengaruhi Tingkat Konsumsi Pangan dan Nonpangan Pada Masa Awal Reformasi. In Ekonomi dan Manajemen Ketahanan Pangan (pp. 119-136). IPB Press.

Chioma, N. J. (2009). Causal relationship between gross domestic product and personal consumption expenditure of Nigeria. African Journal of Agricultural ResearchMathematics and Computer Science Research, 2(8), 179-183. 
Dornbusch, R.; Fischer, B.; Startz, R. (2008). Macroeconomics (Edisi Indo). PT. Media Global Edukasi.

Ekayana, A.; Lestari, E.; Qonita, R. (2013). Analisis Hubungan Proporsi Pengeluaran dan Konsumsi Pangan dengan Ketahanan Pangan Rumah tangga Petani di Kecamatan Sewon Kabupaten Bantul. Universitas Sebelas Maret.

Ghozali, I. (2013). Aplikasi Analisis Multivariate dengan Program SPSS. Badan Penerbit Undip.

Hariyati, Y.; Rahman, R.Y.; Zainuddin, A. (2018). Analisis Kuantitatif: Konsep dan Aplikasi untuk Permasalahan penelitian Agribisnis. Unej Press.

Ilham, N.; Sinaga, B. M. (2007). Penggunaan pangsa Pengeluaran Pangan sebagai Indikator Komposit Ketahanan Pangan. SOCA, 7(3), 1-22.

Illahi, N.; Adry, M.R.; Triani, M. (2018). Analisis Determinan Pengeluaran Konsumsi Rumah Tangga di Indonesia. EcoGEN, 1(3), 549-559.

Kuntjoro, S. U. (1984). Permintaan Bahan Pangan Penting di Indonesia. Institut Pertanian Bogor, Bogor.

Kusumawardhani, N.M.S.; Ayu, MS.; Made, S. . (2012). Faktor-Faktor yang Mempengaruhi PDB Indonesia dengan Persamaan Simultan 2 SLS. E-Jurnal Matematika, 1(1), 99-102.

Murohman. (2011). Analisis Faktor-Faktor yang Memengaruhi Pengeluaran Konsumsi Rumah Tangga di Indonesia (Periode Tahun 2000-2010). Institut Pertanian Bogor.

Persaulian, B.; Hasdi, A.; Ali, A. (2013). Analisis Konsumsi Masyarakat di Indonesia. Jurnal Kajian Ekonomi, 1(2), 1-23.

Purwatiningsi, Y.; Hartono, S.; Masyhuri; Mulyo, J. H. (2010). Pola Pengeluaran Pangan Rumah Tangga Menurut Tingkat Ketahanan Pangan di Provinsi Jawa Tengah. Jurnal Ekonomi Pembangunan, 11(02), 236-253.

Rachman, H. P. S. (2001). Kajian Pola Konsumsi dan Permintaan Pangan Masyarakat Berpendapatan Rendah Jawa Tengah dan Nusa Tenggara Barat. Jurnal Agro Ekonomi, 15(2), 36-53.

Rahardja, P.; Manurung, M. (2008). Pengantar Ilmu Ekonomi (Mikroekonomi dan Makroekonomi). Lembaga Penerbit FEUI.

Siregar, K. (2009). Analisis Determinan Konsumsi Masyarakat di Indonesia. Universitas Sumatera Utara, Medan.

Tapsin, G. (2014). An analysis of household consumption expenditure EA-18. European Scientific Journal (ESJ), 10(16), 1-12.

Varlamova, J.; Larionova, N. (2015). Microeconomic and Demographic of Household Expenditure in OECD Composition Approach to Fiscal Policy Instruction for Principles Students. Journal of Economics Education, 153-173.

Wibowo, R. (2000). Penyediaan Pangan dan permasalahannya. In Pertanian dan Pangan: Bunga Rampai Pemikiran Menuju Ketahanan Pangan (Pertama, pp. 11-36). Pustaka Sinar Harapan.

Widjajanti, E.; Li, E. (1996). Food Expenditure Pattern in Urban and Rural Indonesia: 1981 to 1993. Australian Agribusiness Review, 10(1), 93-111.

Wiranthi, P. E. (2014). Analisis Determinan pengeluaran Konsumsi makro rumah tangga di Indonesia. Signifikan, 3(2), 199-212. 